\title{
Regional Economic Integration and Foreign Direct Investment:
}

\author{
The North American Experience
}

\author{
Magnus Blomström \\ Stockholm School of Economics and NBER \\ Ari Kokko \\ Stockholm School of Economics \\ Steven Globerman \\ Western Washington University \\ Working Paper Series in Economics and Finance No. 269 \\ October 1998
}

\begin{abstract}
This paper examines the relationship between regional economic integration and FDI in North America, where two RIAs have been established over the past decade: a bilateral free trade agreement between Canada and the U.S. (CUSTA) and a trilateral agreement (NAFTA) incorporating Mexico as well. The North American experiences suggest substantially more modest impacts of regional trade agreements on intra-regional trade creation and extraregional FDI stimulation than is associated with the earlier stages of EU integration. At the same time, there is support for the European findings that trade and investment impacts will differ across countries within the integrating region. These results serve as a caution against generalizing from earlier experience when forecasting the impacts of expanded economic integration within Europe or the Americas. The consequences of regional economic integration are sufficiently conditioned by inherited policies, as well as by existing macroeconomic conditions, to make extrapolation from historical experience very risky and potentially misleading.
\end{abstract}

JEL classification: F02, F21, F23

Keywords: Regional integration, foreign direct investment, North America

*This paper is part of the NBER's research programme in International Trade and Investment. The authors thank Bob Lipsey, Deborah Swenson and Alan Winters for helpful comments on earlier drafts and HSFR for financial support. 


\section{Regional Integration and Foreign Direct Investment:}

\section{The North American Experience}

\section{Introduction}

Recent years have witnessed a proliferation of new regional integration agreements (RIAs) throughout the world with acronyms such as APEC (Asia Pacific Economic Council), EU (European Union), MERCOSUR and NAFTA (North American Free Trade Agreement). Moreover, politicians continue to discuss the expansion of existing regional agreements to include more countries (e.g. The Free Trade Area of the Americas), as well as the broadening and deepening of existing trade and investment liberalisation provisions (e.g. APEC).

An important focus of the debate surrounding all regional trade agreements is the likely impact on future rates of investment, especially cross-border investment. For example, Canadian opponents of the Canada-U.S. Free Trade Agreement (CUSTA) argued that there would be a substantial net outflow of foreign direct investment from Canada to the United States, as U.S. subsidiaries in Canada closed inefficient Canadian plants and repatriated production to home country facilities. Similarly, U.S. opponents of NAFTA argued that there would be substantial outward foreign direct investment (FDI) flows from the United States to Mexico to take advantage of relatively low Mexican wages. On the other hand, many economists argued that foreign direct investment flows would be little affected by RIAs, per $s e$, either because the impacts of RIAs on locational preference were likely anticipated and already acted upon by multinational companies (MNCs) or because sunk cost investments were important relative to incentives created by tariff reductions. ${ }^{1}$

The vast majority of studies examining the linkage between foreign direct investment

\footnotetext{
${ }^{1}$ See Rugman and Verbeke (1994).
} 
and regional economic integration focus on the European experience. ${ }^{2}$ Since RIAs are becoming relatively ubiquitous, it seems useful to evaluate the relevant linkage in other regions. This paper examines the relationship between regional economic integration and FDI in North America, where two RIAs have been established over the past decade. Specifically, North American integration encompasses a bilateral free trade agreement between Canada and the U.S. implemented in 1989 (CUSTA) and a trilateral agreement (NAFTA) implemented in 1994 which incorporated Mexico as well.

One feature of RIAs in North America is the economic, political and social diversities of the countries involved. While CUSTA can be characterized as an agreement between two highly developed industrialized countries, NAFTA is essentially a "North-South" agreement. The European internal market programmes by contrast have been largely limited (to date) to a fairly homogenous group of industrialized countries. Therefore, an examination of the RIAs in North America might contribute to a more general picture of the linkage between regional integration and FDI flows.

The remainder of the paper proceeds as follows. Section 2 provides a brief review of theory and relevant empirical evidence bearing upon the linkage between RIAs and FDI. Section 3 summarizes the main features of CUSTA and reviews the trade and FDI experiences pursuant to CUSTA'S implementation. Section 4 provides a similar discussion of the NAFTA experience. Section 5 offers conclusions, and a brief consideration of policy implications.

\footnotetext{
${ }^{2}$ Dunning (1997a, 1997b) surveys and discusses the evidence bearing upon the impact of the European Internal Market Programme on inflows of FDI to the European Community, as well as within the European Community.
} 


\section{Regional Integration and FDI: Theory and The European Experience}

For purposes of this analysis, it is useful to distinguish between two sources of FDI flows: (i) intra-regional flows or flows between individual member countries of the RIA; (ii) extra-regional flows or FDI flows between individual member countries and non-member countries. In fact, the empirical literature largely focuses on one or both of these flows. The available studies tend to concentrate on the relative magnitude of the changes in intra-regional versus extra-regional FDI, as well as changes in intra-regional patterns of FDI.

\section{Theoretical Considerations}

Regional economic integration typically encompasses reductions in regional trade barriers and investment restrictions. ${ }^{3}$ Hence, the impacts of RIAs on FDI flows will ultimately reflect the impacts that trade and investment liberalisation have on location and firm-specific advantages. Changes in location-specific advantages are potentially associated with liberalisation-induced changes in relative costs among member and non-member countries, changes in relative economic growth rates, altered investor perceptions about country-specific political risk, agglomeration economies and so forth. Some of these changes will be the direct result of liberalisation initiatives; e.g. tariff reductions alter the relative advantages of exporting versus establishing foreign affiliates. Other changes will indirectly reflect the consequences of economic integration; e.g. economic integration will affect relative and absolute growth rates which, in turn, should affect FDI flows.

It is obviously quite difficult to identify separately the direct and indirect impacts of RIAs on FDI flows. Hence, most studies do not attempt to specify and estimate "structural"

\footnotetext{
${ }^{3}$ Simple RIAs ordinarily do not seek to harmonize monetary and fiscal regimes, although more ambitious forms of integration, e.g. the European Union, are quite concerned with such issues.
} 
models of the RIA-FDI linkage, and essentially focus on "reduced-form" models in which regional integration is introduced into the evaluation (implicitly or explicitly) as a "dummy" variable separating the policy regime into pre and post-integration periods.

Dunning (1997a) highlights the potential for RIAs to alter firm-specific advantages which in turn, may affect incentives for firms to undertake FDI. For example, an RIA might encourage the geographical concentration of specific industrial activities. If there are significant agglomeration economies in those activities, firms with production facilities in the concentrated locations may enjoy increased efficiency advantages compared to firms operating outside those locations. If the exploitation of any resulting efficiency advantages is best achieved by establishing affiliates abroad (perhaps to distribute and service the parent affiliate's products or to supply the parent with inputs), FDI will increase from the regions enjoying agglomeration economies.

It is also obviously extremely difficult to identify separately the influence of RIAs on FDI flows operating through changes in locational advantages as opposed to firm-specific advantages, especially since the two attributes may overlap to a great extent. Hence, it is unsurprising that empirical studies tent to treat changes in FDI incentives as responses to changes in location-specific influences primarily.

Theory leads to no unambiguous predictions about the net effects of RIAs on internal FDI flows, either on a sectoral or a national basis. This is true largely because trade and capital movements are potentially substitutable as well as complementary modes of serving foreign markets. ${ }^{4}$ All else constant, one would expect net outward FDI flows to be relatively strong in RIA member countries that had attracted substantial amounts of prior inward FDI by maintaining relatively high domestic tariff and non-tariff barriers. Conversely, one would

\footnotetext{
${ }^{4}$ See Caves (1996) for a full discussion of issues.
} 
expect inward FDI to be strong in RIA member countries that enjoy relatively strong locational advantages owing to factor endowments, agglomeration economies, favorable regulatory environments and so forth.

Inflows of FDI from "outsiders" into the region are likely to increase if the average level of protection facing outsiders increases, or if the establishment of an RIA raises fears about future protection. Inflows of FDI may also increase if incoming FDI was initially restricted by the limited sizes of the individual national markets, since the integrated market might be large enough to justify the fixed costs associated with the establishment of new foreign affiliates; however, increased inward FDI would probably not be evenly distributed. Rather, it would be concentrated in geographical areas with the strongest locational advantages. 5

The potential effects of an RIA on outflows of FDI from the integrating region are rarely discussed in formal models. This is mainly due to the simplifying assumption that nothing happens with trade barriers in the rest of the world; however, some changes in outward FDI are feasible even when trade policies in the rest of the world remain unchanged. For instance, it is possible that a firm's capacity to undertake new FDI projects is restricted by its administrative capability or the availability of investment capital (Stevens and Lipsey 1992; Belderbos 1992). To the extent that integration reduced intra-regional FDI, it might increase the scope for outflows of FDI from the integrating area to other regions. Again, it is unclear a priori which regions within the RIA would be relatively large net exporters of FDI.

\footnotetext{
${ }^{5}$ It is also possible to picture situations where RIAs could cause a reduction in FDI from outside the region. Specifically, a possible response to integration could be a consolidation of production establishment with supplies originating from a smaller number of affiliates located in the member countries with the most favorable economic conditions. In this case which, is similar to Kindleberger's (1966) investment diversion case, some countries could experience disinvestments as foreign MNEs concentrated their regional operations in other member countries.
} 
To the extent that RIAs also liberalize the legislative and regulatory environments surrounding foreign ownership and control, an additional stimulus is provided to the FDI process. For example, inward FDI will presumably be encouraged by "national treatment" provisions ensuring that foreign investors are treated no less favorably than domestic investors. The practical relevance of such provisions will depend upon the scope and magnitude of pre-existing legal barriers to inward FDI, as well as the extent and nature of host government discrimination against foreign investors. Since these barriers will vary across industrial sectors and among member countries, the impact of eliminating them through an RIA will likely not affect equally the various member countries. ${ }^{6}$

\section{Empirical Evidence}

As noted earlier, most empirical work on the linkage between RIAs and internal and external FDI flows focuses on the experience following the formation of the European Community. ${ }^{7}$ The general conclusion of these studies is that the first phase of European integration was accompanied by a substantial net increase in both EC-related intra and extraFDI and trade flows; however, the largest increases in FDI were from countries outside the EC, particularly from the United States. ${ }^{8}$ Moreover, the geographical distribution of intra-EC

\footnotetext{
${ }^{6}$ Differences across countries in the impacts of an RIA on aggregate FDI flows will, in turn, reflect differences in the mix of industries at the national level, although the latter is unlikely to change significantly as a result of international trade flows. See Globerman (1992).

${ }^{7}$ For reviews of the European studies, see Yannopoulos (1990) and Dunning (1997 a). Some exceptions to the European focus are early studies of Latin American integration, including Behrman's (1972) study of LAFTA, Mytelka's (1979) study of the Andean Group, and Bulmer-Thomas' (1982) study of the Central American Common Market.

${ }^{8}$ There is no consensus on the reasons for the increased U.S. investment in Europe. Dunning (1997a) argues that the determinants of FDI such as market size and growth, agglomeration economies and so forth were at least as important, if not more so, as the establishment of a common external tariff.
} 
FDI was not uniform: around 90 percent of inbound extra- and intra-EC FDI prior to 1985 was concentrated in the "core" countries of the EC, with the majority located within a 500 mile radius of Frankfurt.

Studies of later stages of European integration have been more mixed in their findings about the linkage between regional economic integration and extra-regional FDI flows. For example, Dunning (1992) claims that the challenges of 1992 have led to a revitalization of U.S. investment in the EC, while Lipsey (1990) concludes that changes in the location of fixed investment by U.S. MNEs were relatively small up though 1989. The upsurge in Japanese investment in Europe has attracted recent attention and the conclusion seems to be that those investments have increased as a consequence of the 1992 program in response to both the opportunities and threats created by the integration process (Thomsen and Nicholaides, 1991, and Balasubramauyam and Greenaway, 1992). More recently, Pain and Lansbury (1997) cite some evidence that the Internal Market process of the EU may have diverted investment into the EU at the expense of other locations. Specifically, the level of inward investment in Europe by U.S. and Japanese firms has been significantly higher since 1987 than might otherwise have been expected.

Focusing on inter-regional FDI, Pain and Lansbury (1997) also argue that German investment in the EU has, on average across sectors and countries, been higher since 1987 than might otherwise have been expected, although there is evidence of considerable variation across countries. ${ }^{9}$ In a related study, Pain (1997) focuses on the determinants of intra-EU FDI from the United Kingdom. In particular, he investigates whether there is any evidence that the

\footnotetext{
${ }^{9}$ They caution that the impact of the programme on within-sector developments cannot be estimated precisely; however, there is some evidence that for manufacturing, the Internal Market programme has diverted investment into the EU, although this does not seem true for the service sector.
} 
foreign investments of UK firms have been diverted into the EU at the expense of the United States. Results suggest that the internal market programme has had a significant positive impact on the stock of UK FDI within the EU, especially in the services sectors. Barrell and Pain (1997) also find clear evidence that the EU Single Market Programme has raised the level of intra-EU FDI significantly, with investment rising more sharply than might have otherwise been expected in those sectors that previously had the highest barriers to crossborder market entry. There is little sign of production facilities dispersed throughout Europe having been amalgamated into a single location.

Compared to the literature linking RIAs to FDI flows for the region as a whole, substantially less attention has been paid to the impact of RIAs on the FDI outcomes for individual countries within the integrating region. The early studies focusing on individual countries include studies on the UK (e.g. Mayes 1983 and Grant 1983) and Ireland (O'Farrell 1983). The results from these studies are mixed. Specifically, while no investment effects were found in the case of the UK, Ireland's membership in the EC stimulated direct investment from both EC and non-EC sources. Winters (1996) notes a similar distinction between Spain and Portugal, on the one hand, and Greece, on the other hand. Spain and Portugal benefited from significant increases in inward FDI as a result of EC membership but Greece did not. Finally, Baldwin, Forslid and Haaland (1996) simulate various scenarios using a computable general equilibrium model. Among other things, they simulate the effects of the 1992 Single Market Programme when the European Free Trade Association (EFTA) is included and excluded from EU 92. Roughly speaking, they find that nations that participated or were expected to participate in the EU experienced rising net FDI inflows. Those that did not participate experienced deterioration of their FDI balance until their government took actions that made it likely that they would participate; however, the impacts were not uniform across countries. For example, FDI inflows into Sweden increased sharply while increases 
were somewhat muted in Finland.

\section{Summary}

Available empirical studies tend to show that RIAs encourage increased intra-regional FDI flows, as well as increased flows from outside the region into the region. They also show that different countries within the integrating region experience different effects. Specifically, while increased net inward FDI tends to be ubiquitous throughout the region, the relative increases vary across member countries. The latter differences undoubtedly reflect to some extent, differences in the relative sizes of industrial sectors among member countries; however, other determinants of differences have also been identified including the degree to which economic integration, directly or indirectly, increases the locational advantages of a country relative to other member countries. Finally, there is only limited evidence that the geographical concentration of economic activity has increased, even in sectors which benefit from economies of agglomeration and plant economies of scale (Dunning 1997a).

\section{The Canada-US Free Trade Agreement (CUSTA).}

The essence of the CUSTA, implemented on January 1, 1989, was the phased bilateral elimination of tariffs. ${ }^{10}$ In addition, a number of provisions reduced discrimination against bilateral foreign direct investment, including the extension of rights-of-establishment and national treatment. A range of prominent sectors, such as basic telecommunications, was

\footnotetext{
${ }^{10}$ The relatively long time lag between the negotiation and implementation of the CUSTA might imply that large Canadian and U.S. firms anticipated the formal integration agreement and adjusted their FDI strategies before formal implementation; however, the Canadian ratification of the CUSTA was very much in doubt pending the outcome of a federal election. It seems, therefore, fair to argue that any significant linkages between the CUSTA and subsequent changes in FDI flows should be identifiable after the CUSTA was implemented.
} 
effectively excluded from coverage under the investment liberalisation provisions of the Agreements. Moreover, Canada's existing foreign investment screening procedures were left in place (Globerman and Walker 1993). The thrust of the investment provisions of the CUSTA was, therefore, to expand the legal scope for bilateral direct investment with important sectoral reservations, especially for service industries. The inclusion of a relatively robust dispute resolution mechanism arguably reduced the risks of either government acting in a discriminatory manner towards investors from the other country, which also should have encouraged increased FDI flows within the region.

The significance of the trade liberalisation provisions of the CUSTA is unclear $a$ priori, since bilateral trade between Canada and the U.S. had been substantially liberalised before the implementation of CUSTA, through successive GATT rounds, as well as special bilateral agreements such as the Auto Pact and the Defense Sharing Agreement. To the extent that CUSTA significantly liberalised intra-regional trade, one would expect to see bilateral trade between the U.S. and Canada increase, both absolutely and relatively to the two countries' extra-regional trade. Moreover, to the extent that trade and FDI are significantly related, either as substitutes or complements, one would also expect to see associated changes in the relative importance of bilateral direct investment between the two countries.

Table 1 reports bilateral trade (exports plus imports) as a share of total trade separately for Canada and the United States. It should be noted explicitly that the series reported do not hold constant all major influences on bilateral trade over time other than the CUSTA. Hence, changes in the series post-1989 may (and presumably do) reflect influences beyond those exerted by CUSTA. Consequently, one must be extremely cautious in drawing any conclusions from Table 1 about impacts of CUSTA, per se, on bilateral trade. With this caveat in mind, the data in Table 1 indicate a fairly steady and significant increase in the relative importance of U.S. trade post-1989 for Canada; however, no similar pattern is 
noticeable for the U.S. with respect to trade with Canada. Specifically, the relative importance of Canada as a trading partner for the U.S. is virtually unchanged when comparing the pre- and post-1989 periods.

Table 2 presents an overview of Canadian FDI patterns between 1983 and 1995. As above, bilateral inward and outward FDI refer to U.S. direct investment inflows to Canada and Canadian direct investment outflows to the US, respectively. Other inward and outward FDI refers to non-US direct investment flows to countries other than the United States. Based upon the data in Table 2 it is possible to calculate the "bilateral intensity" of Canada's FDI flows by dividing the sum of the first two columns by the sum of all four columns and multiplying the ratio by one hundred. Bilateral intensity fluctuates fairly dramatically over the period 1983-1989 and then is relatively stable through 1993. It increases noticeably in 1994 and 1995.

It is tempting to conclude that the CUSTA was relatively neutral between encouraging intra-regional and extra-regional FDI, at least in the early years of the Agreement. The sharp increase in bilateral FDI in 1994 is consistent with European evidence that the impacts of an RIA on FDI is cumulative over time, and may even have been augmented by the implementation of the NAFTA; however, survey evidence suggest that the adjustments of North American MNCs to trade liberalisation had been largely completed by the time of NAFTA's implementation. ${ }^{11}$

Looking specifically at inward FDI from the U.S. relative to inward FDI from elsewhere suggests the degree to which CUSTA encouraged investment diversion from outside the liberalised region to Canada, although the multitude of influences on U.S. versus non-US-based FDI flows to Canada which are not held explicitly constant, makes this simple

\footnotetext{
${ }^{11}$ See, for example, Blank (1993)
} 
ratio a crude indicator, at best, of the significance of investment diversion. While the ratio (not reported) fluctuates quite widely, it is clear (from Table 2) that inward FDI from the U.S. is substantially larger relative to inward FDI from other countries in the 1990s than in the 1980s. This increased emphasis on U.S. investment in Canada in the 1990s is consistent with Canada's increased trade intensity with the United States.

As with the trade experience, the FDI experience of the United States differs from that of Canada. Specifically, there is no evidence that Canada became an increasingly important source of inward FDI to the United States during the 1990s. Indeed, the stock of Canadian FDI to total FDI stock remained virtually constant at around 8 percent. Given the size disparity between the Canadian and United States economies, it is to be expected that most significant changes associated with the CUSTA would be experienced by Canada. Nevertheless, the apparent absence of any noticeable impacts on the bilateral intensity of U.S. trade and FDI flows is suggestive.

Another perspective on the linkage between the CUSTA and intra- versus extraregional FDI flows is provided by the behaviour of Canadian outward FDI. While the absolute (Canadian current) dollar value of outward FDI to the U.S. increased by almost 40 percent, the stock of outward FDI in the U.S. relative to total outward Canadian FDI decreased from around 69 percent in 1985 to around 54 percent in 1995. ${ }^{12}$ Thus Canadian outward FDI flows to regions other than the U.S. increased faster than FDI outflows to the U.S. over the period. This trend largely reflects the much faster rate of growth of outward Canadian FDI to Europe compared to the U.S over the 1990s.

On the surface, the decrease in the relative importance of outward Canadian FDI in the

\footnotetext{
${ }^{12}$ It is possible that the CUSTA had the indirect effect of encouraging extra-regional outward Canadian FDI by securing more unrestricted access for Canadian exports to the U.S domestic market.
} 
U.S. seems inconsistent with Canada's growing trade intensity with the United States. ${ }^{13}$ In fact, the relative increase in U.S. FDI in Canada in the 1990s is the relevant linkage to Canada's increased trade intensity with the United States, since intra-company trade within U.S.-controlled firms is a major channel for Canada's trade with the U.S. To illustrate, in 1992, about 70 percent of the exports of U.S.-controlled firms in Canada was conducted on an intra-company basis, while intra-company exports of these firms accounted for close to 45 percent of all Canada-U.S. exports. ${ }^{14}$ Moreover, the importance of such intra-company trade increased in the first half of the 1990s given the increased absolute and relative importance of automotive products in bilateral trade flows, and the dominance of the Big-Three U.S.-owned automobile companies in the Canadian automotive industry.

In effect, a substantial portion of Canada's increased trade with the United States was accomplished through increased intra-industry trade by U.S. MNC affiliates located in Canada. The capacity of these affiliates was, in turn, expanded through increased U.S. FDI in Canada.

\section{Summary of the CUSTA Experience}

The experience of the CUSTA underscores a finding identified in the literature dealing with European economic integration. Namely, the experiences of individual countries within the integrating region can differ substantially. While unsurprising, the magnitudes of the Canada-U.S. differences in the case of CUSTA are fairly striking. Specifically, U.S. trade and investment intensities with Canada seem little changed as a result of CUSTA, while Canada's trade and inward FDI intensities with the U.S increased modestly, but significantly. The

\footnotetext{
${ }^{13}$ See Strategis, Micro Economic Research and Statistical Analysis, 1998; http//strategic.ic.gc.ca

${ }^{14}$ Ibid.
} 
reasons for the observed differences undoubtedly include differences in the absolute sizes of the two economies which, in turn, give changes in the U.S. variables more weight in the determination of Canadian macroeconomic values than changes in comparable Canadian flows have on U.S. variables. The asymmetry may also reflect the likelihood that Canadian industries were more affected by cross-border restructuring following the implementation of the CUSTA than American industries. ${ }^{15}$

\section{The North American Free Trade Agreement (NAFTA)}

Shortly after the establishment of the CUSTA, Canada and the United States initiated negotiations with Mexico about a possible southern expansion of the integration agreement. In December 1992, the three countries signed the NAFTA. This agreement, which came into effect on January 1, 1994, was the first formal regional integration agreement involving both developing and developed countries. In essence, this agreement is an extended version of the CUSTA. In addition to the trade and investment liberalisation measures already included in the CUSTA, the NAFTA includes major advances in areas such as government procurement (where coverage is extended to services and construction) and intellectual property and investor's rights (introducing binding investor-state arbitration), as well as more stringent rules of origin (see e.g. Hufbauer and Schott 1993 for details).

The overall effects on Mexico of a free trade arrangement with Canada, and particularly with the United States, were expected be significant. ${ }^{16}$ Although Mexico had implemented a substantial amount of unilateral trade and investment liberalisation prior to NAFTA, economists argued that a substantial amount of additional industrial restructuring

\footnotetext{
${ }^{15}$ See the readings in Globerman and Walker, eds., for evidence supporting this assertion.

${ }^{16}$ See Ramirez (1993).
} 
was likely to result from the NAFTA, and that this would likely be accompanied by increased intra-industry trade and investment in Mexico. In particular, Mexican experts anticipated a substantial increase in domestic imports from the U.S. combined with increased FDI from the United States. $^{17}$

In fact, Mexico's trade intensity with its NAFTA partners, of which the United States is the dominant party, increased fairly consistently over the 1990s, as the data reported in Table 3 suggest. ${ }^{18}$ Specifically, Table 3 reports total exports from Mexico, Mexico's exports to the U.S. and Canada (both in absolute value and as a share of total exports), and exports (both absolute and relative values) to other Western hemisphere countries. A similar set of data is provided for imports.

It can be argued from the data in Table 3 that Mexican economic integration with the United States was "deepened" by the liberalisation initiatives that Mexico undertook beginning in the late 1980s. ${ }^{19}$ That is, Mexico's increasing trade intensity with its NAFTA partners is apparent even in the early 1990s. Indeed, there was no notable increase in Mexico's trade intensity with its NAFTA partners in the post-1994 period; e.g. in 1997, the share of total Mexican exports going to the U.S. and Canada was around 86 percent, while the share of Mexican imports originating in the U.S. and Canada was approximately 76 percent, almost exactly what they were in 1993.

Mexico has become both an absolutely (and relatively) larger trading partner from the U.S. perspective in the post-NAFTA period. For example, exports of U.S. goods to Mexico increased by nearly 37 percent over the period. The trend with respect to imports is more

\footnotetext{
${ }^{17}$ Ibid.

${ }^{18}$ In 1997, around 83 percent of Mexico's total exports went to the U.S., while 74 percent of its imports came from the U.S.

${ }^{19}$ For details on the reforms, see Hufbauer and Schott (1992).
} 
dramatic. Imports from Mexico increased by around 84 percent over the period 1994-1996, while total U.S. imports increased by only 36 percent. Nevertheless, several economic studies, which try to hold constant the impact of "other factors" on Mexico's trade with the U.S, conclude that Mexico's recession and the peso depreciation significantly affected bilateral trade flows. The peso depreciation was particularly important in stimulating Mexican exports to the United States. ${ }^{20}$

Table 4 reports FDI flows into Mexico from the U.S. as well as total FDI flows to Mexico for the immediate pre and post-NAFTA periods. A difficulty in analysing Mexican FDI data is the fact that the classification system was changed in 1995 so that intended investment is excluded from the annual total FDI inflows reported after 1995. An implication is that total FDI flows into Mexico were clearly overstated prior to 1995, although it is less clear that the overstatement was biased in favor or against intra-regional FDI flows.

In any event, the data in Table 4 indicate that U.S. FDI flows into Mexico were relatively little changed (in absolute value) in the immediate post-NAFTA period compared to the pre-NAFTA period. While the U.S. share of FDI inflows to Mexico fluctuated fairly widely from a high of 56.8 percent in 1993 to a low of 42.2 percent in 1996 , there is no consistent trend in this statistic. It certainly does not seem possible to conclude that there has been an intensification of either intra or extra-regional FDI in Mexico's case. Moreover, it is likely that the observable changes are largely conditioned by Mexican domestic economic conditions including the peso devaluation in the post-NAFTA period. ${ }^{21}$ Inflows of FDI from Canada to Mexico remain very small in absolute and relative value and are concentrated in the mining sector. The implementation of NAFTA appears to have made

\footnotetext{
${ }^{20}$ See Hinojoso-Ojeda (1996).

${ }^{21}$ Hinojoso-Ojeda (1996) argues that NAFTA had little direct influence on FDI inflows to Mexico.
} 
little difference either to the magnitude or nature of Canadian FDI in Mexico. Outflows of FDI from Mexico also remain notably small in absolute terms.

\section{Summary of the NAFTA Experience}

The impacts of NAFTA on intra-regional and extra-regional trade and FDI flows appear to be quite modest, to the extent they can be documented. It can be argued, as in the case of CUSTA, that the trade and investment liberalisation which preceded the implementation of the Agreement contributed to the apparent failure of the Agreement to create a discrete "regime shift" in intra-regional economic integration. Furthermore, the fact that tariff rates were relatively low in many sectors prior to the NAFTA may have dampened the incentive of non-NAFTA investors to establish production facilities inside Mexico (i.e. investment diversion). In any case, perhaps the main lesson of the NAFTA experience is that "North-South" regional trade agreements need not have dramatic consequences everywhere they are implemented. In this regard, the experiences of poorer countries such as Spain and Portugal upon joining the EU appear to be different from that of Mexico joining the NAFTA. In particular, FDI inflows to Spain and Portugal increased relatively markedly after those countries joined the EU. ${ }^{22}$

\section{Overall Summary and Conclusions}

Fairly straightforward theoretical considerations lead one to expect differences across regions in the economic consequences of trade liberalisation agreements. For example, differences in pre-existing states of economic integration, national economic conditions and the precise terms and conditions of each liberalisation agreement can contribute to substantial

\footnotetext{
${ }^{22}$ See Baldwin, Forslid and Haaland (1996).
} 
divergences in observable experiences.

In this regard, while most of the available empirical research on regional economic integration has focused on the EU experience, the North American experiences under the CUSTA and NAFTA provide a somewhat different picture of the impacts of trade liberalisation. In particular, the North American experiences suggest substantially more modest impacts of regional trade agreements on intra-regional trade creation and extraregional FDI stimulation than is associated with the EU experience, particularly with the earlier stages of EU liberalisation. At the same time, the North American experiences support European findings that trade and investment impacts will differ across countries within the integrating region.

The apparent contrast between the EU and North American experiences serves as a caution against generalizing from either experience when forecasting the impacts of expanded economic integration within Europe or the Americas. While the consequences of regional economic integration are not entirely sui generis, they are sufficiently conditioned by inherited policies, as well as by existing macroeconomic conditions, to make extrapolation from historical experience very risky and potentially misleading. 
Table 1

Bilateral Merchandise Exports + Imports

as a Percentage of Total Exports + Imports

\begin{tabular}{rrr} 
Year & Canada & U.S. \\
1983 & 72.8 & 21.5 \\
1984 & 74.3 & 21.8 \\
1985 & 75.4 & 20.3 \\
1986 & 73.6 & 21.3 \\
1987 & 72.7 & 20.6 \\
1988 & 71.8 & 20.7 \\
1989 & 72.0 & 20.3 \\
1990 & 72.0 & 19.9 \\
1991 & 72.3 & 19.7 \\
1992 & 74.3 & 19.7 \\
1993 & 76.7 & 20.5 \\
1994 & 78.3 & 21.0 \\
1995 & 77.4 & 20.7 \\
1996 & 77.8 & 20.7 \\
1997 & 78.6 & $20.9 *$ \\
\hline
\end{tabular}

*First 3 quarters at annual rate.

Sources: Statistics Canada, Canada's Balance of International Payments, Ottawa: Ministry of Industry, various issues and Council of Economic Advisers, Economic Report of the President, Washington; United States Government Printing Office, various issues. 
Table 2

Inward and Outward Foreign Direct Investment for Canada (millions of Canadian dollars)*

\begin{tabular}{|c|c|c|c|c|c|}
\hline Year & $\begin{array}{c}\text { Bilateral } \\
\text { Inward }\end{array}$ & $\begin{array}{l}\text { Bilateral } \\
\text { Outward }\end{array}$ & $\begin{array}{l}\text { Other } \\
\text { Inward }\end{array}$ & $\begin{array}{c}\text { Other } \\
\text { Outward }\end{array}$ & $\begin{array}{c}\text { Bilateral } \\
\text { Intensity }(\%)\end{array}$ \\
\hline 1983 & 29 & 1,686 & 2,438 & 1,558 & 30.0 \\
\hline 1984 & 3,196 & 3,209 & 2,960 & 1,563 & 58.6 \\
\hline 1985 & -191 & 3,144 & 1,965 & 2,130 & 41.9 \\
\hline 1986 & -743 & 3,362 & 4,607 & 1,502 & 30.0 \\
\hline 1987 & 6,028 & 7,278 & 4,632 & 4,044 & 60.5 \\
\hline 1988 & 2,052 & 2,963 & 5,899 & 1,775 & 39.5 \\
\hline 1989 & 2,091 & 3,510 & 3,850 & 1,918 & 49.3 \\
\hline 1990 & 3,246 & 2,800 & 5,917 & 2,722 & 41.2 \\
\hline 1991 & 1,961 & 1,925 & 1,187 & 4,553 & 40.4 \\
\hline 1992 & 2,719 & 1,315 & 2,673 & 3,144 & 41.0 \\
\hline 1993 & 5,308 & 968 & 1,117 & 6,522 & 45.1 \\
\hline 1994 & 7,279 & 2,456 & 960 & 4,070 & 65.9 \\
\hline 1995 & 10,229 & 3,570 & 5,122 & 2,996 & 63.0 \\
\hline
\end{tabular}

Source: Statistics Canada, Canada's balance of International Payments, Ottawa, Ministry of Industry, various issues.

* Net flows including reinvested earnings accruing to direct investors. 
Table 3

Mexican Exports and Imports 1986-1995

(Million USD; percent of total exports and imports in parentheses)

\begin{tabular}{lrrrrrr} 
& & Exports & & & Imports \\
\cline { 3 - 6 } Year & Total & US + & $\begin{array}{r}\text { Other } \\
\text { Western }\end{array}$ & Total & $\begin{array}{r}\text { US }+ \\
\text { Canada }\end{array}$ & $\begin{array}{r}\text { Other } \\
\text { Western } \\
\end{array}$ \\
& & & & & Hemisphere \\
1986 & 19,074 & 13,928 & 1,120 & 14,749 & 10,666 & 423 \\
& & $(73.0)$ & $(5.9)$ & & $(72.3)$ & $(2.9)$ \\
1987 & 20,532 & 13,577 & 1,589 & 12,758 & 8,626 & 379 \\
& & $(66.1)$ & $(7.7)$ & & $(67.6)$ & $(3.0)$ \\
1988 & 20,409 & 13,726 & 1,482 & 19,557 & 13,401 & 738 \\
& & $(67.3)$ & $(7.3)$ & & $(68.5)$ & $(3.8)$ \\
1989 & 22,975 & 16,364 & 1,496 & 22,789 & 15,911 & 930 \\
& & $(71.2)$ & $(6.5)$ & & $(69.8)$ & $(4.1)$ \\
1990 & 26,247 & 18,711 & 1,589 & 29,556 & 20,236 & 1,252 \\
& & $(71.3)$ & $(6.1)$ & & $(68.5)$ & $(4.2)$ \\
1991 & 27,101 & 19,523 & 1,681 & 38,121 & 26,825 & 1,587 \\
& & $(72.0)$ & $(6.2)$ & & $(70.4)$ & $(4.2)$ \\
1992 & 46,153 & 38,278 & 2,305 & 61,914 & 46,522 & 2,236 \\
& & $(82.9)$ & $(5.0)$ & & $(75.1)$ & $(3.6)$ \\
1993 & 51,832 & 44,474 & 2,554 & 65,188 & 49,284 & 2,320 \\
& & $(85.8)$ & $(4.9)$ & & $(75.6)$ & $(3.6)$ \\
1994 & 60,459 & 52,588 & 2,819 & 79,198 & 56,371 & 2,831 \\
& & $(87.0)$ & $(4.7)$ & & $(71.2)$ & $(3.6)$ \\
1995 & 79,324 & 68,388 & 4,028 & 73,938 & 56,344 & 2,032 \\
& & $(86.2)$ & $(5.1)$ & & $(76.2)$ & $(2.7)$ \\
\hline
\end{tabular}

Source: UN Trade Tapes.

Table 4

Foreign Direct Investment Flows to Mexico

(billions of U.S. dollars)

\begin{tabular}{lllll} 
& 1993 & 1994 & 1995 & 1996 \\
U.S. FDI Inflows & 2.5 & 3.7 & 3.0 & 2.7 \\
Total FDI Inflows & 4.4 & 8.0 & 5.5 & 6.4 \\
U.S. as a Percentage of Total & $56.8 \%$ & $46.3 \%$ & $54.5 \%$ & $42.2 \%$ \\
\hline
\end{tabular}

Sources: IMF, International Financial Statistics (various issues) and International Trade Representative (1992). 


\section{References}

Balasubramanyam, V.N. and D. Greenaway (1992), "Economic Integration and Foreign Direct Investment: Japanese Investment in the EC," Journal of Common Market Studies, Vol. 30, pp. 175-93.

Baldwin, R.E., R. Forslid and J.I. Haaland (1996), "Investment Creation and Diversion in Europe," The World Economy, Vol. 19, No. 6, pp. 635-659.

Barrell, Ray and Nigel Pain (1997), "Foreign Direct Investment Technological Change and Economic Growth within Europe," The Economic Journal, Vol 107, November, pp. 1770-1786.

Behrman, J.N. (1972), The Role of International Companies in Latin American Integration, Lexington, Mass.: Lexington Books.

Belderbos, R.A. (1992), "Large Multinational Enterprises Based in a Small Economy: Effects on Domestic Investment,”Weltwirtschaftliches Archiv, Band 128, pp. 543-57.

Blank, S. (1993), “The Emerging Architecture of North America," in A.R. Riggs and Tom Velk, Beyond NAFTA: An Economic, Political and Sociological Perspective, Vancouver: The Fraser Institute, pp. 22-35.

Bulmer-Thomas, V. (1982), "The Central American Common Market," in A. El-Agraa (ed.), International Economic Integration. London: Macmillan.

Caves, R.E. (1996), Multinational Enterprise and Economic Analysis, Second edition, Cambridge: Cambridge University Press.

Dunning, J.H. (1997a), “The European Internal Market Programme and Inbound Foreign Direct Investment," Journal of Common Market Studies, Vol 35, No. 1, pp. 1-30. (1997b), "The European Internal Market Programme and Inbound Foreign Direct Investment,” Journal of Common Market Studies, Vol. 35, No. 2, pp.: 189-223.

Globerman, S. (1994), "North American Trade Liberalization and Intra-Industry Trade," Weltwirtschaftliches Archiv, Band 128, Heft 3, pp. 487-97. 
Globerman, S. and M. Walker (1993), eds., Assessing NAFTA: A Trinational Analysis, Vancouver: The Fraser Institute.

Grant, R. (1983), “The Impact of EEC Membership upon the UK Industrial Performance,” in R. Jenkins (ed.), Britain and the ECC, Proceedings of Section F (Economics) of the British Association for the Advancement of Science. London: Macmillan.

Hinojosa-Ojeda, R. (1996), "North American Integration Three Years After NAFTA," University of California, Los Angles, mimeo.

Hufbauer, G. C. and J. J. Schott (1992), North American Free Trade: Issues and Recommendations, Washington, D.C.: Institute for International Economics.

International Trade Representative (1997), Economic Effects of NAFTA, Washington, D.C.: U.S. Government Printing Office.

Kindleberger, C.P. (1966), "European Integration and the International Corporation," Columbia Journal of World Business, Vol. 1, pp. 65-73.

Lipsey, R.E. (1990), “American Firms Facing Europe: 1992,” in M. Feldstein and Y. Kosai (eds.), U.S.-Japan Economic Forum, Cambridge: NBER.

Mayes, D.G. (1983), “EC Trade Effects and Factor Mobility,” in A.M. El-Agraa (ed.), Britain Within the European Community: The Way Forward, London: Macmillan.

Mytelka, L.K. (1979), Regional Development in a Global Economy: The Multinational Corporation, Technology, and Andean Integration. New Haven: Yale University Press.

O'Farrell, P.N. (1983), “Ireland,” in L.H. Klaassen and W.T.M. Molle (eds.), Industrial Mobility and Migration in the European Community, Aldershot: Gower.

Pain, N. (1997), “Continental Drift: European Integration and the Location of UK Foreign Direct Investment," TheManchester School Supplement, pp. 94-117.

Pain, N. and M. Lansbury (1997), "Regional Economic Integration and Foreign Direct Investment: The Case of German Investment in Europe," National Institute Economic Review, No. 160, pp. 87-99. 
Ramirez de la, O. R. (1993), “The North American Free Trade Agreement from a Mexican Perspective" in Steven Globerman and Michael Walker, eds., Assessing NAFTA: A Trinational Analysis, Vancouver: The Fraser Institute, pp. 60-86.

Rugman, A. M. and A.Verbeke (1994), "Foreign Direct Investment and NAFTA: A Conceptual Framework" in Alan M. Rugman, ed., Foreign Investment and NAFTA, Columbia: University of South Carolina Press, pp. 80-104.

Statistics Canada (various issues), Canada's Balance of International Payment, Ottawa; Ministry of Industry.

Stevens, G.V.G. and R.E. Lipsey (1992), “Interactions between Domestic and Foreign Investment, Journal of International Money Finance, Vol. 11, pp. 40-62.

Thomsen, S. and P. Nicolaides (1991), The Evolution of Japanese Direct Investment in Europe, New York and London: Harvester Wheatsheaf.

Winters, L.A. (1996), “Lebanon’s Euro-Mediterranean Agreement: Possible Dynamic Benefits," paper prepared for Lebanese Center for Policy Studies' Conference on “Lebanese-EU Relations,” Beirut, July 1-2, mimeo.

Yannopoulos, G.N. (1990), "Foreign Direct Investment and European Integration: The Evidence from the Formative Years of the European Community," Journal of Common Market Studies, Vol. 28, pp. 235-59. 